WIESNER, Claudia - Capitalism, democracy, and the European Union

Zeitschrift für Vergleichende Politikwissenschaft ; Comparative governance and politics, 2016, Vol.

10, No. 3-4, pp. 219-239

First Online: 07 December 2016

\title{
Claudia Wiesner
}

\section{Capitalism, democracy, and the European Union ${ }^{1}$}

\section{Introduction}

\section{The EU: Trojan horse of capitalism or opportunity for representative democracy?}

The question of whether democracy and capitalism can be reconciled is not new, though for a number of decades it was seemingly answered in the affirmative by the majority of political scientists. In recent decades, however, several tensions between democracy and capitalism have become apparent, which severely impede certain basic ideals and elements of representative democracy, such as equality, participation, and political and social rights. These problems have been discussed in a growing number of publications, and have been broached in the present journal through a series of contributions from Wolfgang Merkel (Merkel 2014, 2016) Wolfgang Streeck (2015) and Colin Crouch (2015). The present article seeks to contribute to this debate by placing special focus on the European Union.

In two of the above-mentioned articles - those by Colin Crouch and Wolfgang Streeck - and in several other recent contributions in the debate on capitalism and democracy, the European Union has been discussed in highly critical terms. Wolfgang Streeck, for example, claims that the EU is at the forefront of capitalism's attack on representative democracy, and that in order to save some of the substance of representative democracy, the EU needs to be partially dismantled. On the basis of an argument by German constitutional lawyer Herman Heller (Heller [1933] 2015), a number of scholars have even claimed that the EU is drifting toward an "authoritarian liberalism" that combines economic deregulation with authoritarian dedemocratisation (Menéndez 2015; Scheuerman 2015; Somek 2015).

Other authors do not see the EU in such critical terms and argue that it is possible to reconcile capitalism and democracy in today's EU (see e.g. Merkel 2014, 2016). A straightforwardly positive account of the EU is given by Jürgen Habermas (Habermas 1999, 2001) who regards the EU as a possible means of regulating global capitalism.

\footnotetext{
${ }^{1}$ My special thanks to Johannes Loheide for his thoughtful and reflective discussion of the topic.
} 
Finally, despite such contributions on the question of capitalism and democracy in the EU, the bulk of mainstream EU studies would hardly even think of raising this question - most likely because a free market economy is one of the bases of the EU. The idea that this may pose a problem is by no means widely shared in the academic debate.

Against this backdrop, the present article seeks to further examine the relation between capitalism and democracy in the European Union and to discuss the possible consequences of this relationship for institutional and democratic reform and future developments. Building on the discussion in the four articles noted above, the present article pursues the question of whether there is a possibility of democratic governance in the EU, or whether the EU has to be regarded as the Trojan horse of capitalism.

The next section will recapitulate the main arguments put forward by Crouch, Merkel and Streeck (2). This will be followed by a brief discussion of the institutional dimension of democracy in the EU's multilevel system (3.1.) as well as its politico-cultural dimensions (3.2.). The fourth section will discuss the complex contexts and actors influencing the relation between democracy and capitalism (or rather, liberalization and deregulation) within the EU. In the fifth and final section I shall consider whether and to what extent democracy is possible within the EU's system of liberal capitalism, and how representative democracy in the EU and the EU multilevel system could be safeguarded and improved under current conditions.

\section{The EU, democracy, and globalised capitalism: Pessimism, optimism, or middle ground?}

The connections between capitalism and democracy, their influence upon each other, and the tensions that capitalism has created for democracy since the 1970s have been discussed in depth in the four above-mentioned articles. What all authors agree on is that the dominance of a market-oriented, financialised form of capitalism that has developed since the 1970s threatens representative democracy at its core, since this form of capitalism challenges (Merkel 2014, p. 118): The basic democratic principle that authoritative political decisions can only be taken by those who have earned the requisite legitimacy through constitutional-democratic procedures, and the principle of political equality, which is undermined by the asymmetrical distribution of socioeconomic resources among citizens, largely to the disadvantage of lower social classes. In Wolfgang Merkel's view (Merkel 2014), this brings about four serious problems for representative democracy: 1) socioeconomic inequality leads to political inequality and asymmetrical political participation, 2) elections are increasingly unable to stem growing socioeconomic inequalities, 3 ) the state becomes vulnerable and loses its capacity to act, and 4) 
political decision-making is moved away from parliament to the executive. Merkel concludes that these developments put pressure on four out of the five partial regimes of embedded democracy: elections, political participation, horizontal accountability, and the effective power to govern. He therefore states that "financial capitalism is harmful for democracy as it has cracked its social and political embeddedness" (Merkel 2014, p. 125).

In his contribution, Streeck (Streeck 2015) supports most of these arguments. He disagrees, however, with regard to the third partial regime in Merkel's model of 'embedded democracy': civil rights. While Merkel (Merkel 2014, p. 125) concludes that improvements have been made within this partial regime through a drive toward greater gender equality, civil rights, and strong political NGOs, Streeck declares that such changes are the result of "pseudo-participation in pseudo-debates" (Streeck 2015, p. 52). Nevertheless, decades of gender and civil rights research and related empirical findings on discrimination and its effects have taught us that gender and ethnicity are highly relevant where inequality is concerned. It is not only cultural inequality and feelings of anxiety that manifest along ethnic, gender and educational lines, but also "hard" economic inequality. Moreover, in light of the relevant EU policies, it is no surprise that civil rights have improved in recent decades, as will be discussed below. The field of civil rights and antidiscrimination is one in which the EU and particularly the Court of Justice of the European union (CJEU; formerly European Court of Justice, ECJ) and the EU Commission have fought for positive integration, i.e., the creation of new regulations. This field is therefore particularly interesting in the EU context. Moreover, it seems as if an increase in civil rights goes well together with market liberalisation ta least to some extent. This is a topic that deserves further investigation.

Streeck also highlights two other important points: first, he claims that an awareness of social class and power needs to be restored to mainstream political science more fully; second, he states that it is crucial to include the European Union in any reflection on how capitalism and democracy may or may not be reconciled in future. He rightly argues that "the European Union is now the foremost institution that would need to be 'reformed' if there is to be any restoration of democracy of the sort Merkel has in mind" (Streeck 2015, p. 56).

Streeck's perspective on the European Union is nonetheless highly critical. In his view, the most recent 2014 European Parliament elections amount to an "election charade", in which "a notorious bank lobbyist and privy tax councillor to global corporations [Juncker, was appointed] to the highest office of 'Europe', and in which "there is little hope if any for 'Europe' being of help with Merkel's project to re-establish egalitarian-democratic control over financialized capitalism" (Streeck 2015, p. 56). He therefore concludes that capitalism should 
be de-globalised and that embedded democracy should be restored by re-embedding capitalism at the national level (Streeck 2015 59-60).

In his own reply to Merkel's article, Colin Crouch (Crouch 2015) also takes a critical perspective on the EU. He argues that the EU "has long been an example of post-democracy: an institution with all the formal trappings of democracy, but where these have been developed in a top-down, bureaucratic way [...]". Even if he is sympathetic to Streeck's argument according to which the EU is capable of "promoting non- or even anti-democratic capitalism" (Crouch 2015, p. 69), he departs from him in two respects. First, he is critical of Streeck's advocacy of a return to the national level, since he claims that this, and the ensuing European disintegration, would favour national protectionism and ultimately lead to a more unfavourable state of affairs. Second, he adopts a more optimistic perspective on the EU (see below).

In the final contribution to this debate, Merkel (Merkel 2016) takes up the abovmentioned criticism of the European Union. He also doubts that there would be a simple way of making the EU an agent capable of regulating capitalism:

\begin{abstract}
"It remains unclear if not utopian, however, why the EU, which is characterized by the dominant role of competition law and whose 28 member states have no intention to implement anything like tax harmonization [...] would want to reach a consensus on constructing a truly democratic union that reins in the power of the City of London, puts an end to the free-riding tax polices of low-tax countries [...] and subjects the European Central Bank to democratic control." (Merkel 2016, p. 72).
\end{abstract}

But Merkel ultimately pleads in favour of a form of regulated capitalism in the EU. He argues that it is possible to find a middle ground between optimism and pessimism, on the basis of Harvard economist Dani Rodrik's seven proposals for the regulation of globalized capitalism.

The debate has shown that EU market liberalisation represents a challenge to democracy but to what extent? Is it, then, possible to reconcile democracy and capitalism in the EU? In the following I shall first briefly discuss the current state of representative democracy in the EU, before enquiring into the relations between democracy and capitalism (or rather economic and financial deregulation) in the EU.

\title{
3. Democracy in the EU
}

Before discussing the relationship between democracy and capitalism in the EU context, I shall briefly consider democracy within the EU multilevel system, focussing first on its institutional dimensions and then on its politico-cultural dimensions. 


\subsection{The institutional dimension of democracy in the $\mathbf{E U}$ and the multilevel system}

The question of whether there is a "democratic deficit" in the EU has been discussed in depth since the 1990s. While the positions in this debate are relatively well-known, the underlying problems it has raised are also important for the issues in question here.

To begin with, there is little agreement among academics on the nature of the EU. On one view the EU is considered to be an intergovernmental entity (see e.g. Majone 1998; Moravscik 2002) that does not need to be further democratised since its member states provide it with sufficient legitimation. On another, more recent view, the EU is a political system comparable to other political systems (see e.g. Hix and Høyland 2013; Tömmel 2014) and one that should also be further democratised.

Though this discussion may at first sight appear to be purely academic, it is nonetheless important to an understanding of the different ways in which one might evaluate the EU. If one takes the view that the EU is an intergovernmental entity, one will be rather sceptical about the necessity and possibility of democratising the EU, whereas if one regards the EU as a political system, this implies that it can also potentially be a kind of full-fledged representative democratic system - whatever this means concretely in the multi-level practice.

The argument presented in the following is based on the view that a) the EU is to be regarded as a political system that $b$ ) has been increasingly democratised and c) should still be further democratised. From this perspective, a number of critical remarks can be made with respect to the EU level (see Føllesdal and Hix 2006; Hix 2008 for overviews). Yet it is important to stress that any assessment of the EU's democratic character should moreover take into account the whole multilevel system, i.e., the EU and its interrelations with its 28 current member states. From this standpoint, a number of flaws and democratic challenges can be observed that regard the institutional dimension.

First, EU policies are no longer merely regulative; they also have redistributive effects (Beetham and Lord 1998, pp. 17-19; Føllesdal and Hix 2006, p. 551). The EU therefore exerts a strong influence on the everyday life of its citizens. This fact indicates the need for substantial democratic legitimation of the EU and its policies, including the dimension of input legitimacy. Second, legitimation chains in the EU are still long and rather opaque, so that accountability is not always easily attributable. Council members, for instance, receive their legitimation through national elections and national parliaments, i.e. by way of a long chain. Commission members are appointed by the member states' governments, though after a number of political struggles the EP has obtained the right to approve the Commission as a body and to influence the selection of the Commissioners to a certain degree (see Tiilikainen and Wiesner 2016). 
Third, input legitimacy is still weaker at the EU level than in the member states' own democracies (Beetham and Lord 1998, pp. 17-19; Bellamy and Castiglione 2003). National representative democracies therefore comply better with the needs of democratic input legitimacy, yet they have continued to transfer competencies to the EU level in various ways (see below). In consequence, European integration has led to a net loss of input legitimacy within the multilevel system (Beetham and Lord 1998, pp. 17-19; Habermas 1999, pp. 186187).

Fourth, and directly related to this, EU institutions have enlarged their competencies in recent decades without acquiring a representative-democratic legislative underpinning equal to that of its member states. Since in this same period the representative democracies and legislatives of these member states saw their competencies partly transferred to the EU, executive powers generally increased in the EU multilevel system, while legislative powers decreased (Føllesdal and Hix 2006, pp. 534-537; Mény 2003). Moreover, crucial powers were also transferred to the EU's judiciary branch and to agents and agencies (see below in detail).

In sum, decision-making powers in the EU multilevel system have been continually withdrawn from the sphere of representative democracy and political participation (Habermas 2001). The balance has shifted in favour of the executive and judiciary branches. Rather than a politicization of EU-politics, we can thus observe its de-politicisation (Checkel and Katzenstein 2009; Diez Medrano 2009; Mény 2003).

The Lisbon Treaty has served to remedy certain of these issues, particularly by assigning greater powers to the directly elected European Parliament (EP). In a number of policy areas, the latter is now the first legislative chamber, and along with the Council is jointly responsible for decision-making. Nevertheless, the short account of the EU's democratic deficit given above has already indicated that the problem setting is more complex. Precisely locating the EU's institutional democratic deficit is far from a simple matter and requires a careful examination of the dynamics of legitimacy, democracy, and the balance of powers within the multi-level system as a whole.

\subsection{The politico-cultural dimensions of democracy in the EU and the multi-level system}

A second strand of the debate around democracy and the democratic deficit in the EU addresses the question of whether the EU has, or can have, a proper demos. As the argument at the heart of this debate claims, input legitimacy requires a democratic subject that can properly grant it. It is often argued that the population of the EU is a long way from constituting such a demos. This too represents a decisive move in the debate: if there is no demos that can legitimately provide input-legitimacy, on what basis should the representative institutions work? Such 
arguments inevitably lead to the favouring of output or throughput legitimacy, as has been repeatedly claimed by Fritz Scharpf (Scharpf 1999).

The question of whether the EU can develop a fully fledged demos and whether it is already on the way to doing so cannot be discussed here in detail (see Wiesner 2014a for a detailed treatment), though a few remarks can be made on this subject. Democracy needs to be based on a demos, a democratic subject, that at least minimally a) defines itself as such (through the mutual recognition of the citizens or demos-members), b) identifies with the EU as a polity (e.g. through identification and support), and c) is politically active in the EU as a polity (Wiesner 2014a, pp. 38-43).

There is nonetheless good reason to believe that in the EU such a democratic subject is already in development. To take just one indicator, drawn from Eurobarometer data, we can observe that the majority of EU citizens identify themselves as citizens of the EU. According to the last Eurobarometer Survey (Eurobarometer 2016, p. 38), roughly two thirds of EU citizens say so (66\%). In 26 member states, the majority of citizens say that they feel this way. There is, however, considerable national variation: in Luxemburg, nearly all citizens feel themselves to be EU citizens (93\%), followed by Malta (84\%), Finland (82\%), and Ireland (80\%). Interestingly enough, a majority of UK citizens (53\%) also say so. In Italy and Bulgaria only $49 \%$ of people feel this way, and Greece is the only member state where the majority of citizens do not feel themselves to be EU citizens (54\% No and $46 \%$ Yes). Since all Eurobarometer polls have indicated a severe reduction in people's identification with and support for the EU and its policies in the countries hit hardest by the financial crisis, this is hardly surprising.

Without claiming that such a sense of EU citizenship is by itself sufficient for strong input legitimacy that would also justify redistributive policies, it may be argued that it perfectly qualifies EU citizens to be the demos that elects the EP. Yet it is also true that, alongside this EU-related demos, the EU will depend in future on the stronger demoi within the member states and the member state-related input legitimacy they provide, and this speaks all the more in favour of taking the whole multi-level system into consideration when discussing democracy in the EU. In sum, we can speak here both of stronger, older, national demoi on the one hand, and a more recent, weaker, EU-related demos on the other. ${ }^{2}$

While I therefore claim that there is enough of a demos in the EU to enable input legitimacy at the EU level, a further significant finding in the field of politico-cultural studies is that

\footnotetext{
${ }^{2}$ This argument differs from that made within the demoicracy debate: proponents of demoicracy mainly argue that only national demoi can provide a legitimating foundation for the EU (see e.g. Nicolaïdis 2013).
} 
throughout the recent financial crisis, identification with, trust in, and support for democratic institutions at both the EU and the national level have decisively shrunk (see the Eurobarometer results since 2008; Eurobarometer). Between 2011 and 2013, for instance, more than $60 \%$ of those polled by Eurobarometer did not feel that their voice counted in the EU and only around $30 \%$ of those polled felt that their voice did count. Trust in EU institutions declined by approximately 20 percentage points between 2007 (around 50\%) and 2015 (just above 30\%). Furthermore, trust in national parliaments and national governments, which is usually lower than trust in EU institutions, also declined in parallel, from 35\% (parliaments) and 34\% (governments) to $28 \%$ (parliaments) and $27 \%$ (governments). While trust in the EU thus declined more decisively, national institutions were also severely affected by the effects of the financial crisis on citizens' trust. This indicates, first, that in the multilevel system legitimacy beliefs no longer are solely directedat either the EU level or the nation state level, since these two are linked. Second, it indicates that the sovereign debt crisis has affected citizen's views on the EU. In this regard, the EU's input legitimacy deficits have increased during the crisis.

\section{Democracy in the EU's system of liberal capitalism}

Returning now to the topic of democracy and capitalism in the EU, the key question is whether the EU is the Trojan horse of capitalism, or whether capitalism can be restrained within or by the EU. In the following, I shall argue for a position of enlightened optimism, according to which the EU can restrain capitalism under certain conditions and circumstances.

\subsection{Is the EU an agent of capitalism, or does it only act as such?}

Taking our cue from an expression that sprang up in German social democratic thinking in the debates around "Stamokap" theory, the first crucial question we need to ask here is whether the EU is a natural agent of capitalism or whether it only acts as such. My claim is that it only acts as such. There are nevertheless a number of complex reasons as to why it does so.

The first of these lies within the EU's historical origins. The initial aim of European integration was not to found a supranational democratic federation, nor to regulate capitalism, as the European Federalist movements had wished. Its initial goals were to create a balance of power in Europe, to centralise control over the core industries of coal and steel, and to integrate into the Western political sphere a West Germany that would be subject to long-term control. Economic integration was seen as the tool capable of realizing all of these goals. The project was based on nation states and national governments, and integration was to be fuelled by the economic and political self-interest of the latter. 
This direction of integration relates to a decisive failure. The draft treaty on a European Political Community (EPC) was close to ratification in the early 1950s. Related to the existing European Community of Coal and Steel and also to the Plan for a European Community of Defence (EDC), the EPC Treaty foresaw a fully fledged, two chamber parliament. One chamber was to be directly elected by EU citizens, the other was a senate consisting of delegates from the national parliaments. A draft constitution was even developed on the initiative of the ECSC foreign ministers (Europäische Politische Gemeinschaft 1953). But ratification of the EPC Treaty was stopped in 1954 by the French parliament, and plans for the strong democratisation of the EU were brought to a halt for some time. Afterwards, in the first three decades of the integration process, integration focused on the creation of an internal market (Wiesner 2014b). This historical background provides us with the first key reason as to why the EU is able to act as an agent of economic liberalisation. The EU treaties, i.e., the EEC, ECSC and Euratom treaties and those that followed, make a point of abolishing all obstacles to a successful internal market. On the basis of these treaties and the four classical freedoms (free movement of trade and goods, services, labour, and capital) obstacles to the free market were successively abolished. In other words, it can justifiably be claimed that the EU treaties helped and still help to pave the way for market liberalisation, removing all possible barriers to free trade. In several cases, national social standards have been interpreted as being such barriers (see below).

Deregulation served the interests of what in the US is often termed "big money" rather than small enterprises. Financial industries and big companies emerged as the winners of this process, while small businesses and agricultural entrepreneurs lost out. Furthermore, while younger and highly skilled individuals benefitted from the right to free movement, a new EUproletariat also emerged. In the city of Frankfurt, some EU citizens will earn a fortune in investment banking, while other EU citizens working on the ECB building site are almost completely lacking in rights due to their status as posted workers - a status that largely invalidates German trade union action and social laws (Lilie 2016).

The treaties themselves, however, are only part of the explanation. An important role was also played by their interpreters, namely the EU Commission and the Court of Justice of the European Union (CJEU, formerly the European Court of Justice, ECJ). In a German-language article, Dieter Grimm (Grimm 2014) described the role of the latter, noting two decisive factors: first, the ECJ acted as an agent of integration and deregulation; second, the EU treaties, in the form of EU primary law, regulate policy fields that would normally be subject to secondary law. 
Grimm summarises the underlying story as follows: after the projects of the EPC and the EDC had failed, a common market was the easy way out, since it could be planned and built in a technical and non-political manner, i.e., without broad public debate. It could also be legitimized through its success. In the seemingly non-political EEC, politics - in the sense of debating, offering alternatives, working on pros and cons - was restricted to the nation state level.

The ECJ acquired its key role through two rulings it passed in 1963 and 1964 that claimed EU law to be superior to nation state law-a move that has been interpreted as a constitutionalisation of the treaties. And it indeed was a decisive move, since the treaties regulate a number of fields and issues that in a nation state would fall under secondary law. Constitutions usually focus on questions of polity and politics, whereas the EU treaties emphasize economic policy. A related debate emerged within the French discourse on the Constitutional Treaty in 2005, when critics argued that the words "free market" appeared over a hundred times in the draft Constitutional Treaty, whereas the word "democracy" rarely was mentioned (Wiesner 2014a). In sum, the EU treaties have shifted extensive policy fields out of the usual realm of political decision-making in representative democracies.

Since a constitution is not normally subject to political debate, but only to legal interpretation, and since it is difficult to change EU primary law, this has led to a further reduction of the field of potential political discussion and decision-making (Grimm 2014, pp. 1050-1052). The field of legal interpretation was broadened on the other hand, and the interpreter of the treaties, the ECJ, thus acquired considerable influence. It used its interpreter role to drive forward negative integration without creating new regulations, since in almost every case it decided in favour of abolishing obstacles to the internal market - even where these represented national social standards. The ECJ was, in Grimm's words, a "court with a political agenda" (Grimm 2014, pp. 1046-1051).

Yet the former ECJ was not alone in driving forward economic deregulation in the EU. Representative democratic institutions also played their part in the process. Here too the picture is complex. With the EU Treaties providing a framework, the Commission proposed the relevant legislation. The liberalisation agenda was therefore also driven by the Commission, and particularly by its DG for competition. Furthermore, EU legislators, i.e., the governments of the member states and the European Parliament, often voted in favour of deregulation. This means that both the governments of member states and the EP at least helped to pave the way 
for market liberalisation. But why, then, did they play the game, rather than trying to create more positive integration?

First, this may be explained on the basis of policy preferences. During the first decades of integration, member state ministers were the sole legislators in the EEC and EC and hence voted on the new laws concerning the creation of the EU's internal market. From the 1970s onwards and particularly after the social democratic era, the governments casting their votes in the Council were increasingly led by conservatives and/or liberals. Following the shift from Schmidt to Kohl in 1990s Germany, for instance, economic policy increasingly took on a liberal market orientation. Third way social democrats like Tony Blair and Gerhard Schröder continued this trend. Liberal market oriented governments not only shaped their own national economic policies, but also influenced deregulation policies in the EU through their votes in the Council. Deregulation was in their political interests, yet the usual game played 'at home' was to claim that it was not the respective governments that were responsible for it, but rather the EU.

Since the Maastricht Treaty introduced a joint decision-making process between the European Parliament and the Council, the EP has regularly played a role in determining internal market legislation. In other words: the European Parliament voted for several of the EU laws that reduced obstacles to free-market competition. The relevant decisions were therefore jointly taken by the EU's representative democratic parliament and the Council, and are thus underpinned by the EP's voter input legitimacy. Some prime examples of such laws will be discussed below.

Policy preferences again provide one explanation of this development. In recent decades, the European Parliament contained large groups of liberals and conservatives. These groups were often in the majority. The EP therefore could not constitute a serious obstacle to the deregulation agenda led by the Commission, the Council and the ECJ. Its dominant political groups and the fact that it needed to act in a united manner in order to be heard led it to support deregulation with only a few exceptions.

Moreover, there are a number of indicators that lobby groups and economic players tried to influence legislation procedures and governance in the policy fields that were discussed ${ }^{3}$. In November 2016, 10447 lobby groups are officially registered at the European Union (European Commission 2016). Moreover, there are direct personal relations between the now bankrupt American investment bank Goldman Sachs and the ECB, as today's ECB president Mario

\footnotetext{
${ }^{3}$ There is a great number of publications that study lobbying in the EU, see, e.g., Rasmussen 2015; Dürr and Mateo 2014.
} 
Draghi formerly was vice-chairman of Goldman Sachs (Streeck 2015: 132). It is, however, difficult to prove the influence of lobbies or personal relations without specific and detail case studies that would need to be carried out in each case of legislation.

A further explanation for the Council's and the European Parliament's decision-making is that first the relevant national governments and then the EP majority bound themselves to the rules of the financial markets. As Wolfang Streeck discusses in detail in his book Buying Time, the new common currency in the 1990s was not prepared by an economic government that worked in favour of economic cohesion. Instead, the convergence criteria, which put restrictions on the member states' spending, were set up as conditions for accessing into the Eurozone (Streeck 2014, pp. 97-164). The convergence criteria can be seen as an anticipation of today's austerity regime. Since most member states and a majority of the European Parliament supported the convergence criteria, this binding of Europe's institutions to financial austerity continued from the 1990s onwards.

It is only after the legislative processes sketched above that the ECJ came in and subsequently interpreted the new rules, and usually as much in favour of re-regulation as possible, thereby creating new legal practices (see below). Grimm (Grimm 2014, p. 1050) argues in this regard that the Council is a weak legislator because its members do not share similar interests and because law-making is dependent on initiatives proposed by the Commission. Moreover, he claims that member state governments did not overlook the full consequences of the ECJ decisions.

Most evaluations of the EU's institutional system, however, would not subscribe to the view that the Council is a weak legislator (Hix and Høyland 2011; Tömmel 2014), even if they might agree on the diversity of member states' interests. And can it really be claimed that national governments did not "overlook" the game the ECJ would play? It seems unrealistic to expect them to be uninformed in this regard. And if they really were, it would seriously question their capacity to govern. A legislator, after all, should be aware of the policy outcomes its laws may give rise to, even if these only emerge after judiciary action.

Deregulation in the EU has therefore been supported by the relevant representative-democratic institutions, i.e., both by national governments and the EP. This brings us to a question raised in Merkel's 2016 article, namely, why does the EP electorate, and why do the EU member states' electorates, accept their representatives' subscription to market liberalisation and its effects, i.e., the dismantling of the bases of social and political equality? One possible answer to this question is that the electorate is not even aware this is happening, since EU policies are highly complex and difficult to understand. Another possible answer is that EU laws are often 
only discussed in the respective member states when they are implemented at the national level; in other words, debate does not take place before a given policy is determined, but only afterwards.

What has been sketched so far shows that a complex set of actors and political decisions led the EU to act as an agent of economic deregulation. Alongside the major role played by the ECJ, the Commission, the respective governments of the member states, and the EP all contributed to this process, since they were responsible for (jointly) deciding in favour of deregulation - be it because it was in their political interest, or because they bound themselves to a programme of financial austerity.

Three conclusions follow from this: First, then, one would not be justified in arguing that this process was non-democratic as a whole, or that it only took place behind closed doors. In truth, many layers of political action and representative-democratic decision-making lay behind the deregulation process. Second, this fact cannot be underestimated in assessing the relationship between democracy and capitalism in the EU. We cannot simply speak of a conspiracy of "neoliberals" that led the EU in the wrong direction. Neither can we conclude that only the former ECJ, or the DG for competition are the villains of the piece. The picture is much more complicated than this, as was noted above in discussing the "democratic deficit". Third, this means that it is theoretically possible that the actors in question might decide to act otherwise, even in such a way that the EU could come to defend democracy against capitalism, economic circumstances permitting.

\subsection{Negative integration and its impact on social rights}

It is ironic that the EU, which originated as an intergovernmental organization rather than a supranational democracy, has helped to dismantle the sovereignty of its member states by means of liberalisation. The EU's liberal market orientation has come into conflict with its member states' representative democracies in several respects. Two examples shall be briefly sketched here: a) social and workers' rights and b) the governance of the financial crisis (see 4.3.).

Social rights can be considered an elementary prerequisite of democracy (for a detailed discussion see Wiesner 2012) in the sense that unfettered social inequality hinders equal democratic participation and representation. In the history of modern citizenship, social rights such as the right to social protection have been bound to nation states. In order to be sustainable, social rights require a solid financial basis. Thus far, only nation states have been able to provide this basis, since only they can collect the necessary taxes - at least as long as the EU does not 
obtain a right of taxation (a proposal that has been repeatedly discussed). While they themselves have not produced equality, tax-financed schooling, healthcare, and childcare benefits have helped to equip most citizens with a material and educational basis for social and political participation. Nevertheless, the substance of social rights has been diminished through the financialisation of capitalism and EU austerity programmes. Social benefits and the safety nets of the welfare state have been curtailed in order to increase member states' competitiveness in a globalised economy. Alongside rising income inequality, this has contributed to increasing inequalities in social and political participation.

Furthermore, negative integration has also had problematic effects. EU-specific citizenship rights are mainly comprised of market-related freedoms, in addition to a core set of political rights linked to EU citizenship. Thus far, social rights have rarely been defined at the EU level (for a detailed discussion see Wiesner 2007). Moreover, negative integration has also affected national social rights. Two ECJ judgements are highly instructive here. The posted workers directive (European Union 2006) stipulates the conditions governing workers posted to other EU member states. The cases of Rüffert and Laval were concerned with the working conditions in the states to which these workers were posted, as well as the right of trade unions to protest these conditions. In its rulings, the ECJ attempted to interpret these rights as narrowly as possible, arguing explicitly that the posted workers directive defined maximum rather than minimum standards. Member states receiving posted workers could therefore only demand that the posting companies keep to the standards defined in the directive. In the Rüffert case (European Court of Justice 2008), the ECJ judged that the German federal state of Lower Saxony could not take action against a German company that did not pay the agreed wages to workers employed by a Polish subcontractor. In the Laval case (European Court of Justice 2007), the ECJ even decided that national trade unions could only protest or launch strike action against companies that are not resident in the respective member states if the issues concerned were covered by the posted workers directive. As a result, national governmental actors and trade unions are only able to take action in the few cases touched on by the posted workers directive. In all other cases, legal action or strikes against companies that bypass national social standards are legally excluded.

\subsection{Austerity, financial crisis and representative democracy}

The financial crisis gave rise to a number of new challenges for national representative democracies in the EU's multilevel system (for a detailed discussion see Wiesner 2016). The governance structures for the budgetary aid dispensed through the European Stability 
Mechanism (ESM) constitute an intergovernmental structure parallel to the institutional system comprised by the EU treaties. The current ESM is an intergovernmental construction based on a treaty concluded between the Eurozone member states (European Council 2012). Nevertheless, the actors involved in the ESM are to a large extent identical to the EU actors under the Lisbon Treaty, comprising heads and/or ministers of member states, the EU Commission, and the European Central Bank (ECB).

The oft-cited "Troika" consisting of representatives of the EU commission, the ECB, and the International Monetary Fund (IMF) not only monitors all conditions linked to any financial assistance, but is also in charge of negotiating these terms and formulating them in memoranda of understanding in accordance with Article 13 of the ESM Treaty (European Council 2012). The Troika therefore has a decisive yet highly opaque role in crisis management. The ESM Treaty determines the members and the general tasks of the Troika, yet it neither sets limits on its competencies nor establishes standards for its accountability. In particular, it remains unclear: if and to what extent the Troika's powers supersede those of member states, their governments, and their parliaments; how the Troika's powers relegate to the Troika - the ECB, the Commission, and the IMF; and how they relate to the Eurogroup's governments. This structure is opaque and its accountability remains unclear.

To better understand the setting, it is helpful to look at what happened in reality. The Greek case is instructive in this regard. The results of the Greek bailout negotiations, the memoranda of understanding, hint at the budgetary rights of the Greek parliament being at least severely impeded. The memoranda define very detailed measures and spending cuts, naming percentages as well as areas and programmes in which the cuts need to be carried out (European Commission 2012, 2015).

Yet budgetary rights are to be understood, for good reasons, as one of the crown jewels of a parliament: a budget symbolically and materially expresses the will of the parliamentary majority by way of defining specific policies and a budget for them. Even if the Greek parliament voted in favour of the memoranda in each case (in the case of the first memorandum, however, only in an unconstitutional emergency law), this does not mean that it actually had something substantial to decide upon. The conditions were so detailed that there was little room left for any substantial parliamentary decisions on the budget. Yet a parliament that ultimately cannot decide on the details of its budget and between genuine budgetary alternatives has lost its core role as a parliament. Its decisions are then not only de-politicised, but also void of the substance of parliamentarianism. In such cases, parliament's role is limited simply to holding 
referenda (voting merely yes or no) rather than the core parliamentary tasks of deliberating and voting.

Furthermore, the horizontal balance of powers between member states was impeded by the new developments, since the parliaments of donor states were able to jointly decide on the conditions for budgetary aid. As a result, the German Bundestag was able to have a say on the Greek budget - a side-effect that was surely never intended by the treaties.

Finally, the financial crisis has given rise to two further challenges for democratic nation states. The first is a conflict between creditworthiness and national sovereignty. Where a state loses the confidence of the financial markets, its sovereignty is severely impeded, as the Greek case also demonstrates.

The second challenge concerns the role of austerity regulations in this context. The conditions of financial assistance, far more explicitly than the convergence criteria, effectively function as concealed national objectives - concealed because not even the EU treaties define financial austerity as a goal. In the debtor state Portugal the president made this explicit when he stated in the aftermath of an election that he would only name a new government that accepted the Troika's conditions. But most EU states today are subject to austerity programmes that influence policies to a considerable extent. Even donor states and all other member states that are subject to the Fiscal Compact or the European Semester regulations have to accept the austerity conditions contained therein.

How should these developments be assessed? Are they part of a de-democratising trend within the EU? Are they even a sign of a rising "authoritarian liberalism"? Or do they simply constitute a strange new framework that is nonetheless legitimate in the context of the treaties (MüllerGraff 2011)?

Here I would again argue for the middle ground. The financial crisis presents representative democracy in the EU with a number of new challenges. The Eurogroup and particularly the members of the Troika make themselves agents of the financial markets when they claim that states must accept austerity conditions in spite of the results of democratic elections and referenda. The financial crisis is therefore a blatant example of shifting decision-making powers not only to executives, but also to agents that formally act on behalf of EU institutions or Eurozone members, and all behind closed doors. Yet there are alternatives to such practices.

\section{Democracy and capitalism reconciled in the EU?}

In sum, of the four challenges to democracy discussed in the above-mentioned articles (see Merkel 2016, p. 63 for a summary) we can conclude that two are manifested starkly in and by 
the EU: a vulnerability to state-capture by powerful economic interests and the shifting of political decision-making powers away from parliaments to executives and - we should add the judiciary and agents acting for the EU's institutions or Eurozone member states. In the following I shall claim that there are possible solutions to these problems.

\subsection{Can the EU regulate capitalism?}

The first question to be addressed is whether the EU is at all able to help regulate financial capitalism. My claim is that there are a number of good reasons to think that it is only the EU that can do so, rather than any nation state. While one might argue that Germany is an influential enough economic power to be a global player, Belgium and Lithuania, for example, are not. In a globalised economy, a return to the nation state hence would not help to protect democracy against capitalism - at least as long as globalised capitalism is not significantly re-embedded. But this idea seems far more utopian than the possibility of the EU contributing to the regulation of financial capitalism. In a globalised capitalist world, the EU is the only political actor that can exert a decisive enough influence in favour of an increased market regulation. In his abovementioned article, Colin Crouch offers a pessimistic version of this argument:

"I am forced to argue that to reassert democracy against global capitalism requires a move from a more democratic (national) gremium to a less democratic (European) one. But this is because the former simply cannot tackle the task required at the necessary level. If the neoliberal direction of travel of European integration cannot be turned, I see no level of action powerful enough to do the task at all." (Crouch 2015, p. 71).

A more optimistic version of this argument can nonetheless be offered. First, the EU is capable of helping to regulate globalised financial capitalism simply because of its size: the EU's internal market is large enough to impose conditions on investors and force them to adapt to these. It exceeds China's internal market in size, and China, for instance, was able to force Google to change its policy by threatening to deny market access. Second, if a global player of the EU's size were to lead a united global attempt to regulate financial capitalism rather than supporting deregulation, it could thereby contribute to introducing greater regulation and reembedding capitalism in the global context. Third, the EU has repeatedly given proof of this capacity in dealing with global players such as Microsoft and Google. It was EU competition law, driven by the DG for competition and the ECJ, that hindered Microsoft's and Apple's attempts to establish de facto monopolies. It was also the Commission's DG for competition that proposed the abolition of roaming costs for mobile phones. The EU data protection rules were also successfully defended by the ECJ against Facebook. Fourth, there is proof that the EU is capable of creating positive integration, as evinced by its directives on antidiscrimination. 
The EU's antidiscrimination rules were pushed forward by the Commission, the Council, the European Parliament, and the ECJ acting to a large extent in unison, and the rules are so farreaching that member states such as Germany were forced to considerably improve on their previous rules in this area (for a detailed discussion see Wiesner 2007).

The way in which the EU might become a bulwark against financialised capitalism, or even a major contributor to its re-regulation, may seem surprisingly simple at first sight. I would argue that, in principle, the EU would need to use the very means that helped to embed capitalism in the nation state context in the first place: legislation that regulates the economy and protects democracy, along with political debates about the goals of economic policy. Due to the complexity of the EU context discussed above, however, it will be much more complicated to successfully apply these measures at the EU level than at the nation state level.

\subsection{Reconciling democracy and capitalism in the EU: between big and pragmatic solutions}

In order for the EU to become an agent capable of regulating financialised capitalism, it would need to pass laws promoting positive integration and re-regulation both internally and externally. But the political majorities in the European Parliament and in the EU's member states would need to support this approach. This means that a political battle on this topic would have to be waged - and won - in the 28 (soon-to-be 27) member states.

Furthermore, the differentiated integration that we are currently experiencing would need to be questioned. There are different degrees of integration in different policy areas, and there are different degrees of integration among different groups of member states. The EU is thus dispersed across a wide range of different regulation regimes and schemes, including joint decision-making processes in the internal market, an intergovernmental Common Foreign and Security Policy, the Eurogroup that unites the euro-countries, and the Schengen System that is yet another structure that is only partly linked to the EU. This dispersion of a polity as big as the EU also creates differing patterns of legitimisation and control. While this practice worked successfully for quite some time, it seems to have been brought to an end by the current migration and euro "crises". If the EU were to successfully contribute to re-embedding capitalism, this dispersion would have to be overcome to some extent at least.

In order to reduce the CJEU's role as an agent of liberalisation, it would be necessary to change large swathes of the EU's primary law into secondary law, so that economic policy goals could be subject to political debate and politicised decision-making. But this would require a major treaty change, which under current EU conditions seems highly unlikely, especially since some 
of the member state governments (Germany first of all) would not subscribe to the goal of politicising, democratising, and regulating economic policymaking in the EU.

Moreover, were these changes to be implemented, the EU's task would be to contribute to reducing the current trend toward a two-thirds society in which a third of the citizens have decoupled from economic and social participation. This would require not only economic regulation, but also job creation and changes to production conditions and practices in the EU - and hence at least a partial re-regulation of the globalised economy, or the creation of an EU "jobs miracle".

Neither of these changes seems likely in the foreseeable future. Thus far, there is little agreement even on the basic goals of the EU. Should it simply continue to construct an internal market, as it has so far? Should the EU be rebuilt or scaled down? Or should the EU constitute a means of creating a truly supranational democracy and work to regulate capitalism?

Given the obstacles to turning the EU into a unified actor in re-embedding capitalism, I would like to suggest six possible paths to achieving this goal, each of which differ with respect to the degree and the range of political action they would require. Even in cases where agreement is extremely difficult to reach, the last path will remain a viable option.

1) The "big solution" would be to turn the EU into a force against globalised, deregulated, financialised capitalism, by winning political battles in this field in at least two thirds of the soon-to-be 27 member states, including the larger member states.

2) The "second biggest solution" would be to politicise the EU by de-constitutionalising a large amount of EU secondary law, as discussed above. This could be combined with the following:

3) Halting differentiated integration and re-integrating the EU. Differences between fully and partly integrated policy fields and different forms of regulation, law-making and policy-making could be reduced and ultimately abolished. At the same time, joint decision-making should become the legislative norm in all of the EU's policy fields.

4) Creating a fully fledged and democratically legitimized transfer union in the EU - even if it would remain to be discussed whether such a transfer union could be sustainable in light of the persisting economic differences within the EU.

5) Establishing a Eurochamber in the European Parliament as a democratic co-legislator for the Eurogroup - this would at least increase legitimacy and accountability in the Eurozone, even if the ultimate outcome might not significantly change.

6) The most minimal solution would be to defend what there is to be defended, i.e., to limit the untoward effects on national representative democracies. EU-led policies, as has 
been discussed, threaten the democratic standards and rights of the EU's member states. In order to remedy this problem, transparency, accountability and the vertical balance of powers need to be better protected, i.e. key decision making powers have to be taken away from indirectly legitimized agents such as the Troika. Furthermore, the substance of parliamentary decision-making competencies needs to be safeguarded even under austerity conditions, for example by defining the amounts of expenditure that would need to be reduced, but not the policies required to do so.

In conclusion, there is no more nor less reason why the EU should be an agent or even the Trojan horse of capitalism than that a nation state should be. In light of the foregoing discussion, it does not seem to be an option to just wait and see how the crisis will go on. Continuing disintegration (Britain might not be the last member state to exit the EU), growing criticism of the EU, increasing problems of governance and cooperation at the EU level (e.g. in the field of migration and refugees), and growing inequalities between both citizens and EU member states rather serve to increase the pressure on all of the plyers mentioned - including member state governments and parliaments, the European Parliament, the Commission, and even the CJEU (formerly the ECJ) and the ECB.

But while there is pressure to act, it seems difficult to predict whether there will indeed be action and which direction it might take. The EU currently is torn into several different directions. Brexit is taken as a reason against further integration and regulation by many member state governments especially in Eastern Europe. Fear of right-wing and left-wing populists and their potential victories in the forthcoming national elections such as in France also seems to speak against "more Europe". Commission and European Parliament, and in particular their presidents Juncker and Schulz, on the other hand, seem to recognise the pressure to act very well and claim it openly.

As there is a dissensus on the EU and its state of the art, why not discuss this openly after all? There is good reason to have an open, public, and political debate about the EU and its political goals in all of the member states, by politicians and citizens alike, and there is no reason to avoid it. On the contrary: if defenders of representative democracy do not stage this debate, it may simply be led by extremists, populists and antidemocrats. It seems to be time for a new battle of ideas on the future of the EU, and it seems to be time for politics, finally. 


\section{Bibliography}

\section{EU Documents and Websites}

Eurobarometer. 2016. Standard Eurobarometer 85, Spring 2016. http://ec.europa.eu/COMMFrontOffice/publicopinion/index.cfm/Survey/getSurveyDetail/i nstruments/STANDARD/surveyKy/2130. Accessed 08.11.16.

Eurobarometer. Public Opinion - European Commission. http://ec.europa.eu/COMMFrontOffice/publicopinion/index.cfm/Survey/index\#p=1\&instru ments=STANDARD\&surveyKy=2130. Accessed 08.11.16.

Europäische Politische Gemeinschaft. 1953. Entwurf zu einem Vertrag über die Satzung der Europäischen (Politischen) Gemeinschaft (EPG). http://www.politischeunion.de/epg1.htm. Accessed 05.02.13.

European Commission. 2012. Memorandum of Understanding. http://ec.europa.eu/economy_finance/eu_borrower/mou/2012-03-01-greece-mou_en.pdf. Accessed 30.10.12.

European Commission. 2015. Memorandum of Understanding between the European Commission and the Hellenic Republic and the Bank of Greee. http://ec.europa.eu/economy_finance/assistance_eu_ms/greek_loan_facility/pdf/01_mou_2 0150811_en.pdf. Accessed 18.10.16.

European Commission. 2016. Transoarency Register. http://ec.europa.eu/transparencyregister/public/homePage.do. Accessed 21.11.16.

European Council. 2012. Treaty establishing the European Stability Mechanism. http://www.efsf.europa.eu/attachments/esm_treaty_en.pdf. Accessed 11.09.12.

European Court of Justice. 2007. Judgment of the Court (Grand Chamber) of 18 December 2007. Laval un Partneri Ltd v Svenska Byggnadsarbetareförbundet, Svenska Byggnadsarbetareförbundets avdelning 1, Byggettan and Svenska Elektrikerförbundet. http://curia.europa.eu/juris/liste.jsf?language=en\&num=C-341/05. Accessed 08.11.16.

European Court of Justice. 2008. Urteil des Gerichtshofes (Zweite Kammer) vom 3. April 2008. Dirk Rüffert gegen Land Niedersachsen. http://curia.europa.eu/juris/liste.jsf?language=de\&num=c-346/06\#. Accessed 08.11.16.

European Union. 2006. DIRECTIVE 2006/123/EC OF THE EUROPEAN PARLIAMENT AND OF THE COUNCIL of 12 December 2006 on services in the internal market. http://eur-lex.europa.eu/legalcontent/EN/TXT/PDF/?uri=CELEX:32006L0123\&from=DE. Accessed 08.11.16.

\section{References}

Beetham, David and Christopher Lord. 1998. Legitimacy and the European Union. In Political Theory and the European Union, eds. Albert Weale and Michael Nentwich, 1533. London: Routledge.

Bellamy, Richard and Dario Castiglione. 2003. Legitimizing the Euro-'Polity' and its 'Regime' The Normative Turn in EU Studies. European Journal of Political Theory 1 (2): 7-34.

Checkel, Jeffrey T. and Peter Katzenstein. 2009. The politicization of European Union identities. In European identity, ed. Jeffrey T. Checkel, 1-25. Cambridge [u.a.]: Cambridge Univ. Press.

Crouch, Colin. 2015. Comment on Wolfgang Merkel, "Is capitalism compatible with democracy?". Zeitschrift für Vergleichende Politikwissenschaft 9 (1-2): 61-71. 
Diez Medrano, Juan. 2009. The public sphere and the European Union's political identity. In European identity, ed. Jeffrey T. Checkel, 81-107. Cambridge [u.a.]: Cambridge Univ. Press.

Duerr, A. and G. Mateo. 2014. The Europeanization of interest groups. Group type, resources and policy area. European Union Politics 15 (4): 572-594.

Føllesdal, Andreas and Simon Hix. 2006. Why there is a Democratic Deficit the EU: A Response to Majone and Moravscik. Journal of Common Market Studies 44 (3): 533-562.

Grimm, Dieter. 2014. Europa ja - aber welches? Merkur 68 (797): 1045-1059.

Habermas, Jürgen. 1999. Braucht Europa eine Verfassung? Eine Bemerkung zu Dieter Grimm. In Die Einbeziehung des Anderen, 185-191. Frankfurt am Main: Suhrkamp.

Habermas, Jürgen. 2001. Euroskepsis, Markteuropa, oder Europa der (Welt-)Bürger. In Zeit der Übergänge, 85-103. Frankfurt am Main: Suhrkamp.

Heller, Hermann. [1933] 2015. Authoritarian Liberalism? European Law Journal 21 (3): 295301. http://dx.doi.org/10.1111/eulj.12125.

Hix, Simon. 2008. What's wrong with the European Union and how to fix it. Cambridge, Malden, MA: Polity.

Hix, Simon and Bjørn K. Høyland. 2011. The political system of the European Union. 3rd ed. Basingstoke: Palgrave Macmillan.

Hix, Simon and Bjørn Høyland. 2013. Empowerment of the European Parliament. Annual Review of Political Science 16 (1): 171-189.

Lilie, Nathan. 2016. The Right not to have rights. Theoretical Inquiries in Law 17 (1): 39-62.

Majone, Giandomenico. 1998. Europe's "Democratic Deficit": The Question of Standards. European Law Journal 4 (1): 5-28.

Menéndez, Agustín J. 2015. Hermann Heller NOW. European Law Journal 21 (3): 285-294. http://dx.doi.org/10.1111/eulj.12135.

Mény, Yves. 2003. De la démocratie en Europe: Old Concepts and New Challenges. Journal of Common Market Studies 41 (1): 1-13.

Merkel, Wolfgang. 2014. Is capitalism compatible with democracy? Zeitschrift für Vergleichende Politikwissenschaft 8 (2): 109-128.

Merkel, Wolfgang. 2016. The challenge of capitalism to democracy. Zeitschrift für Vergleichende Politikwissenschaft 10 (1): 61-80.

Moravscik, Andrew. 2002. In Defence of the "Democratic Deficit": Reassessing Legitimacy in the European Union. Journal of Common Market Studies 40 (4): 603-624.

Müller-Graff, Peter C. 2011. Euro-Budgethilfenpolitik im rechtlichen Neuland. Integration (4): 289-307.

Nicolaïdis, Kalypso. 2013. European Demoicracy and Its Crisis. Journal of Common Market Studies (JCMS) 51 (2): 351-369.

Rasmussen, Maja K. 2015. The Battle for Influence. The Politics of Business Lobbying in the European Parliament. JCMS: Journal of Common Market Studies 53 (2): 365-382.

Scharpf, Fritz W. 1999. Governing in Europe. Oxford: Oxford university press.

Scheuerman, William E. 2015. 'Hermann Heller and the European Crisis: Authoritarian Liberalism Redux?'. European Law Journal 21 (3): 302-312. http://dx.doi.org/10.1111/eulj.12126.

Somek, Alexander. 2015. Delegation and Authority: Authoritarian Liberalism Today. European Law Journal 21 (3): 340-360. http://dx.doi.org/10.1111/eulj.12132.

Streeck, Wolfgang. 2014. Buying time. The delayed crisis of democratic capitalism. Brooklyn, NY: Verso.

Streeck, Wolfgang. 2015. Comment on Wolfgang Merkel, "Is capitalism compatible with democracy?". Zeitschrift für Vergleichende Politikwissenschaft 9 (1-2): 49-60.

Tiilikainen, Teija and Claudia Wiesner. 2016. Towards a Political theory of EU Parliamentarism? In Parliament and Parliamentarism. A comparative history of disputes 
on a European concept, eds. Pasi Ihailainen, Cornelia Ilie and Kari Palonen, 292-310. New York: Berghahn Books.

Tömmel, Ingeborg. 2014. The European Union: what it is and how it works. Houndsmills: Palgrave Macmillan.

Wiesner, Claudia. 2007. Bürgerschaft und Demokratie in der EU. Münster: Lit.

Wiesner, Claudia. 2012. Bürgerschaft, Demokratie und Gerechtigkeit in der EU. In Demokratie und Gerechtigkeit in Verteilungskonflikten, eds. Regina Kreide, Claudia Landwehr and Katrin Töns, 185-210. Baden-Baden: Nomos.

Wiesner, Claudia. 2014a. Demokratisierung der EU durch nationale Europadiskurse? Strukturen und Prozesse europäischer Identitätsbildung im deutsch-französischen Vergleich. Baden-Baden: Nomos.

Wiesner, Claudia. 2014b. From Safeguarding Peace in Europe to Financial Crisis: Old questions and new challenges of EU integration. In The Meanings of Europe, eds. Claudia Wiesner and Meike Schmidt-Gleim. London: Routledge.

Wiesner, Claudia. 2016. Gewaltenteilung und Demokratie in der EU-Finanzhilfenpolitik. In Gewaltenteilung und Demokratie im EU-Mehrebenensystem, eds. Miriam Hartlapp and Claudia Wiesner, 231-249. 